\title{
STANDING UP FOR NOTWITHSTANDING
}

\author{
PETER H. RUSSELL
}

The author responds to and criticizes the attack of Professor John Whyte on the notwithstanding clause in the Canadian Charter of Rights and Freedoms. After quickly dealing with several of the admittedly bad reasons for inclusion of the notwithstanding clause, the author puts forward his case for the override focusing on the substantive outcomes of decision-making, as well as the process of decision-making itself. The author supports his views by considering two test cases: The Elections Act Case and The Quebec Signs Case. Finally, the author takes issue with White's treatment of Canada's basic constitutional principles and their bearing on the override issue. The author concludes that it would not be sound to let all public issues which may be adjudicated under the Charter fall to be settled by judges, and he then uses this conclusion to refute the arguments put forward by Professor Whyte.
L'auteur critique l'attaque du Professeur John Whyte contre la clause nonobstant contenue dans la Charte canadienne des droits et libertés. Après avoir traité rapidement de plusieurs des mauvaises raisons, il l'admet, qui ont motivé l'inclusion de la clause nonobstant, l'auteur présente ses propres arguments en s'attachant tant aux résultats importants qu'd la démarche des prises de décisions. L'auteur appuie sa position en examinant deux causes décisives: l'une portant sur la loi électorale et l'autre sur l'affichage au Québec. Finalement, l'auteur remet en question la façon dont White traite les principes constitutionnels fondamentaux du Canada et leur répercussion sur la clause dérogatoire. L'auteur conclut qu'il serait malsain de laisser les juges statuer sur toutes les questions publiques qui pourraient relever de la Charte. Il utilise cette conclusion pour réfuter les arguments avancés par le Professeur Whyte.

\section{TABLE OF CONTENTS}

I. INTRODUCTION . . . . . . . . . . . . . . . . . 293

II. BAD REASONS FOR THE NOTWITHSTANDING CLAUSE . . . . . . 294

III. THE CASE FOR OVERRIDE $\ldots \ldots \ldots \ldots \ldots \ldots \ldots \ldots \ldots \ldots 295$

A. SUBSTANTIVE CONSIDERATIONS $\ldots \ldots \ldots \ldots \ldots \ldots \ldots 295$

B. PROCESS CONSIDERATIONS $\ldots \ldots \ldots \ldots \ldots \ldots \ldots \ldots . \ldots \ldots$

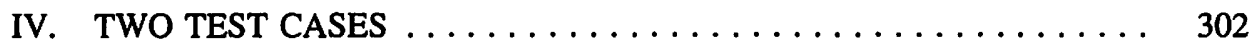

A. THE ELECTIONS ACT CASE $\ldots \ldots \ldots \ldots \ldots \ldots \ldots \ldots, 302$



V. THE PERSPECTIVE OF PRINCIPLE $\ldots \ldots \ldots \ldots \ldots \ldots \ldots \ldots . \ldots \ldots$

\section{INTRODUCTION}

This Review's first annual supplement on constitutional issues includes an essay by Professor John Whyte putting the case against the notwithstanding clause in the Canadian Charter of Rights and Freedoms. ${ }^{1}$ Whyte's article is the most fully reasoned attack we have had on the Charter's override clause. It is an important contribution to our

- Dept. of Political Science, University of Toronto.

I. J.D. Whyte, "On Not Standing for Notwithstanding" (1990) 28 Alta. L. Rev. 347. 
constitutional debate which certainly deserves a reply from one of those singled out, quite rightly, by Professor Whyte as a defender of the override.

Although I readily confess to being a supporter of the override clause, I am not at all satisfied with Professor Whyte's understanding of the rationale for such a clause. Unfortunately, instead of carefully examining the scholarly writings of those who have defended the override, he cites only a portion of one sentence from an "opinion piece" in the Toronto Star by Professor Paul Weiler and myself and a few words from a passage in Professor Hogg's book on the Constitutional Law of Canada. The words quoted and the arguments he proceeds to knock down do not come close to providing an acceptable justification of the Charter's notwithstanding clause.

\section{BAD REASONS FOR THE NOTWITHSTANDING CLAUSE}

The passage quoted from our Toronto Star piece draws attention to the distinctively Canadian manner in which the notwithstanding clause balances the British tradition of responsible democratic government with the American tradition of judicially enforced constitutional rights. I would certainly agree with Professor Whyte in dismissing arguments for the override clause that depend primarily on showing that it is distinctively Canadian. I am sure there are plenty of things that are distinctively Canadian that are perfectly dreadful. The point we were making is that the override gives Canada an opportunity to get the best out of British and American constitutionalism, the two traditions which have profoundly influenced our constitutional development. Professor Whyte, unhappily, may be right, and as English Canada moves ever closer to Charter worship, it may no longer be distinctively Canadian to try to strike a shrewd balance between the wisdom derived from these two parts of our heritage.

It may well be true, as the quotation from Professor Hogg suggests, that political defenders of the override have most often couched their arguments in terms of the need to preserve the principle of parliamentary sovereignty. Again, I am in agreement with Professor Whyte that the case for the override cannot rest on a simple invocation of that principle Even if one were to accept, as I do not, a purely Burkean standard for constitutional development and insist that our constitutional future never break from inherited tradition, it simply is not true that the Canadian constitution historically has been based on the principle of parliamentary sovereignty. No Canadian legislature or parliament has ever been sovereign and I hope none ever shall be. ${ }^{2}$ Legislatures in colonial Canada were subject to important controls, and since 1867, Canadian legislatures have been, subject to judicially enforceable limitations, limitations based on more than preserving the federal division of powers.

2. Although, collectively, the federal parliament and the provincial legislatures might now be considered "sovereign" in Canada since under Part V of the Constitution Act, 1982, in various combinations these legislatures have the power to amend the Constitution of Canada. 
Equally unacceptable as a defence of the override is an appeal to simple majoritarianism. The crude utilitarian standard of "the greatest happiness of the greatest number" is an unacceptable ethical foundation for a constitutional democracy. Liberal democracy requires much more than giving free play to the preferences of the majority. Professor Whyte delineates a number of the "deeper conditions" of democratic government: "political participation, equality, autonomy and personal liberty. ${ }^{3}$ Professor Ronald Dworkin in his contribution to the same issue of the review cogently argues that democratic government should not be founded on a statistical, head-counting conception of political equality but on a communal understanding in which citizens share equally the responsibilities of determining what is right for their political community. ${ }^{4}$

With all of this I whole-heartedly agree. The override should not be defended on the grounds that appointed judges must never be able to thwart the will of a body elected by the majority. Such an argument would rest on the most simplistic and illiberal conception of democracy, a conception oblivious to the need for checks and balances as a condition of liberty and oblivious to the injustices which a majority may wish to inflict on a minority. Such a simplistic and morally shallow theory of democracy is not held by this defender of the notwithstanding clause, nor, I suspect, by most others who see its merits.

Now, having cleared away the underbrush of unacceptable arguments for the override, I shall attempt to put forward what I regard as the strongest grounds for retaining this provision in the Canadian Charter of Rights and Freedoms. These are the arguments which Professor Whyte does not address.

\section{THE CASE FOR THE OVERRIDE}

The major arguments in support of a legislative override turn on considerations about the substantive outcome of decision-making and about the process of decision-making in a liberal democracy. Let me deal first with substantive considerations.

\section{A. SUBSTANTIVE CONSIDERATIONS}

In a nutshell, the argument about the substance of decision-making is as follows. Judges are not infallible. They may make decisions about the limits and nature of rights and freedoms which are extremely questionable. There should be some process, more reasoned than court-packing and more accessible than constitutional amendment, through which the justice and wisdom of these decisions can be publicly discussed and possibly rejected. A legislative override clause provides such a process. At the core of this argument is recognition of the kind of questions courts typically deal with in interpreting and applying a constitutional charter of rights. These are questions not about the validity of the core values enshrined in the general language of the Charter - freedom of speech,

\footnotetext{
3. Supra, note 1 at 352

4. R. Dworkin, "Equality, Democracy and Constitution: We The People in Court" (1990) 28 Alta. L. Rev. 324.
} 
fundamental justice, equality - but about the proper limits of rights based on these values. $^{5}$ It is a truism that no single right should be treated as an absolute. This truism is recognized in section 1 of the Charter which states that all the rights in the Charter are "subject to reasonable limits prescribed by law as can be demonstrably justified in a free and democratic society." It is also recognized in decisions of the Supreme Court of Canada eliminating certain kinds of claims from the definition of the entrenched right or freedom. ${ }^{6}$ Thus, it is quite misleading to describe what the courts are doing in deciding Charter cases as "guaranteeing" that citizens enjoy the rights entrenched in the Charter. What judicial review under the Charter guarantees is careful consideration by the judiciary of a citizen's claim that a Charter right or freedom has been unreasonably encroached upon by a law or executive act of government. In dealing with such a claim the court must decide whether it should be upheld or whether it should give way to other important rights or interests with which it conflicts.

Consider the Supreme Court of Canada's decisions on claims based on section 2(b), the freedom of expression section of the Charter. In these cases the Court has determined whether the following were reasonable limits on the constitutional right to freedom of expression:

- a Criminal Code provision requiring that a trial judge, on the request of a complainant in a sexual assault case, ban publication of information identifying the complainant, ${ }^{7}$

- an injunction issued by a judge, ex parte, prohibiting striking court workers from picketing courthouses, ${ }^{8}$

- a law prohibiting commercials directed at children under $13,{ }^{9}$

- an order from a labour relations board requiring an employer to write a letter of recommendation about a wrongfully dismissed employee, ${ }^{10}$

- a law requiring French-only commercial signs and firm names, ${ }^{11}$

- a law prohibiting publication of the details of evidence adduced in matrimonial proceedings. ${ }^{12}$

In the first four of these cases the Supreme Court decided that the limit on free speech was justified and in the latter two that it was not. One does not find in these cases the Court defending citizens against government attacks on what is fundamental to the right

5. I have developed this point more fully in "The Political Purposes of the Canadian Charter of Rights and Freedoms" (1983) 61 Can. Bar Rev. 30.

6. See, for example, Justice Wilson's restrictive interpretation of the right to security of the person in Operation Dismantle Inc. v. R. [1985] I S.C.R. 441, and Chief Justice Dickson's denial of corporate economic claims as part of the right to liberty in Irwin Toy Limited v. A.G. Quebec, [1989] 1 S.C.R. 927.

7. R. v. Canadian Newspapers Company, [1988] 2 S.C.R. 122.

8. British Columbia Government Employees' Union v. A.G. British Columbia, [1988] 2 S.C.R. 214.

9. Irwin Toy Limited v. A.G. Quebec, [1989] 1 S.C.R. 927.

10. Slaight Communications Incorporated v. Davidson, [1989] I S.C.R. 1038.

11. Ford v. A.G. Quebec, [1988] 2 S.C.R. 712.

12. Edmonton Journal v. A.G. Alberta, [1989] 2 S.C.R. 1326. 
of free speech in a democracy, the right to criticize the government and advocate opposition to it. Instead, in each case the Court dealt with an issue at the margin, not at the core, of free speech and whether such a marginal claim should give way to some other value. In effect, in these cases, the Court was making decisions about the policy of free speech - how far this essential democratic right should be extended and under what circumstances and for what purposes it should be subject to restrictions.

In making the case for a legislative override in the Charter, one need not, and indeed should not, argue that the judiciary should play no part in policy decisions such as these. I agree with Professor Whyte that "Canada, in enacting the Charter of Rights, accepted that some political problems were capable of adjudication...."13 But Professor Weiler and I and other defenders of the notwithstanding clause part company with Whyte when he contends that these issues must be "ultimately adjudicable", ${ }^{14}$ that once the judiciary has spoken there must be closure on these issues.

Far from its being the case, as Professor Whyte claims, that we Canadians in adopting the Charter committed ourselves to having questions about the limits of rights and freedoms ultimately determined by the courts, our constitution-makers in 1982, through the override clause, provided for a partnership between legislatures and courts. In Professor Weiler's words: ${ }^{15}$

Under this approach judges will be on the front lines; they will possess both the responsibility and the legal clout necessary to tackle "rights" issues as they regularly arise. At the same time, however, the Charter reserves for the legislature a final say to be used sparingly in the exceptional case where the judiciary has gone awry.

Under the Charter we can certainly benefit, in ways described by Professor Whyte, by having "rights" issues systematically ventilated in the courts. Most often we will accept the decisions of the courts on these rights issues. But occasionally situations will arise in which the citizenry through a responsible and accountable process concludes that a judicial resolution of a rights issue is seriously flawed and seeks to reverse it. These are the situations in which we should enjoy the benefit of the legislative override.

For anyone familiar with the history of judicial review in the United States or in our own country, it is difficult to believe in the infallibility of judges. In American history, the decisions of the Supreme Court in Lochner and other early twentieth century cases denying state legislatures the power to ensure vulnerable workers decent conditions of employment are reminders of the injustice and harm that can flow from judicial decisions

\footnotetext{
13. Supra, note 1 at 351.

14. Ibid.

15. P.C. Weiler, "Rights and Judges in a Democracy: A New Canadian Version" (1984) 18 University of Michigan Journal of Law Reform, 51 at 84.
} 
interpreting constitutional guarantees. ${ }^{16}$ Already under the Charter, several judicial decisions vetoing legislation might be questioned for the harm they inflict on vulnerable groups in Canadian society. One example is the decision of the Ontario Court of Appeal that in certain circumstances it would be an unreasonable limitation on an accused's Charter rights to give effect to the recent amendment of the Criminal Code protecting complainants in sexual assault cases from being forced to give evidence on their prior sexual conduct. ${ }^{17}$ Another is the decision of the British Columbia Court of Appeal overturning provincial regulations designed to channel the influx of new doctors to areas of the province where they are most urgently needed, ${ }^{18}$ a decision from which the Supreme Court of Canada has denied leave to appeal.

Countries without legislative overrides in their constitutional bills of rights have other means of reversing judicial decisions. In no constitutional democracy is there absolute closure on rights issues once they have been pronounced upon by the judicial branch. The most direct method of reversal is constitutional amendment. But in most constitutional democracies (and certainly in Canada), amending the constitution is an extraordinarily difficult process which may leave decision-making power in the hands of a small group of people who are indifferent to or beneficiaries of the injustice resulting from a judicial decision. The more usual method of reversing constitutional decisions of the courts, at least in the United States, is to change or threaten to change the composition of the judicial bodies most influential in interpreting the constitution. ${ }^{19}$

Absent a Canadian-style legislative override, court-packing or court-bashing are the devices to which democratic leaders are most likely to resort when faced with judicial interpretations of the constitution they consider to be seriously unjust and harmful. These devices may yield relatively quick results as was the case with Roosevelt's threat to pack the U.S. Supreme Court, or they may work much more slowly, as has been the case with the efforts of Republican Presidents to reverse certain decisions of the Warren Court. In either case court-packing or court-bashing, involving as they do the application of raw majoritarian power to the judicial branch, would seem less appropriate devices than legislative debate and discussion for challenging judicial decisions. The legislative override has the merit, when properly used, of applying reasoned discussion in a publicly accountable forum to the great issues of justice and public well-being at stake.

Now it will be noticed that I have qualified my support of the legislative override by arguing for its superiority "when proper used". By "properly used" I mean when it is

16.

There are of course many accounts, but for a brief discussion of these cases see A.T. Mason and W.M. Beaney, The Supreme Court in Free Society (Prentice-Hall, 1959) c. 11.

17. $\quad$ Seaboyer v. R. (1987), 37 C.C.C. (3d) 53.

18. Wilson v. Medical Services Commission of British Columbia (1988), 53 D.L.R. (4th) 171. But see Justice Lamer's condemnation of Wilson in Reference Re Criminal Code, ss. 193 \& 195.1(1)(c) (1990), 77 C.R. (3d) 1 (S.C.C.).

19. For an overview of political constraints on the U.S. Supreme Court see W. Lassser, The Limits of Judicial Power: The Supreme Court in American Politics (Chapel Hill: University of North Carolina Press, 1988). 
invoked only after a reasoned debate in the legislature. This is precisely the point about the override which the Supreme Court of Canada failed to grasp in Ford ${ }^{20}$ when it upheld Quebec's blanket use of the override. The Court held that legislatures are not even required to name the rights or freedoms which are to be restricted. By insisting on an entirely formal approach to the override clause, as Professor Lorraine Weinrib has put it, $^{21}$

The Court thereby defers to a legislative process devoid of its legitimating qualities of reasoned and focused debate by the people's representatives.

The Supreme Court's approach to the notwithstanding clause, unfortunately and ironically, is a departure from the purposive approach applied to other sections of the Charter. The primary purpose of the override is to provide an opportunity for responsible and accountable public discussion of rights issues, a purpose that may be seriously undermined if legislatures are free to use the override without discussion and deliberation.

At this point it is essential to turn to the second wing of the argument for the Charter, the argument that focuses on the process advantages of the override. It is only when we recognize the contribution an override can make to the quality of democratic government that the inadequacy of the Supreme Court's ruling on section 33 can be fully understood and the merits of the notwithstanding clause fully appreciated.

\section{B. PROCESS CONSIDERATIONS}

A legislative override does not guarantee that we will arrive at the right answers to the questions of political and social justice raised by the Charter. What it can do is subject these questions to a process of wide public discussion so that the politically active citizenry participate in and share responsibility for the outcome.

The advantage of retaining a role for legislatures in the determination of rights issues is not to ensure that the will of the majority prevails. Even if one accepted a simplistic majority rule conception of democracy (which this writer does not), the decisions of legislatures can rarely be realistically equated with the will of the majority. This is especially true of legislative decisions on the issues of moral conscience and justice raised by questions about the appropriate limits of rights and freedoms. The point of maintaining parliamentary bodies in a democracy is not to ensure that majority preference gets its way on all public issues. Given the wonders of modern electronics, we do not need legislative chambers to register citizens' preferences. No, the fundamental purpose of parliamentary bodies is to facilitate the democratic ideal of government by discussion. A parliament must above all be a "talking place" - that is, after all, the root meaning of the term. Through media coverage of legislative debates, citizens are engaged in

\footnotetext{
20. Supra, note 11.

21. L. Weinrib, "Learning to Live with the Override" (1990) 35 McGill L.J. 541 at 570.
} 
deliberating on public issues. It is through parliamentary institutions that we move closer to experiencing a form of democratic government that is not simply rule of the greater number but that, in the words of Ernest Barker, ${ }^{22}$

...elicits and enlists - or at any rate is calculated to elicit and enlist, so far as is humanly possible the thought, the will, and the general capacity of every member...a government depending on mutual interchange of ideas, on mutual criticism of the ideas interchanged, and the general capacity of every member.

Much the same democratic ideal is put forward by Professor Dworkin in his recent contribution to this journal. Dworkin rejects what he calls a "statistical democracy" whose institutions are designed simply to ensure that political decisions match the will of the majority. Instead he argues for a "communal democracy" in which ${ }^{23}$

each citizen insists that his political convictions are in every important sense his business, that it is his independent responsibility to decide what is required of the nation to do well, and whether or how far it has succeeded.

We have much less chance of realizing Barker's or Dworkin's democratic ideal, if, as Professor Whyte insists, we give judges the last word, the ultimate say, on rights issues raised by the Charter. To exclude citizens and their elected legislators from the ultimate determination of these issues is to exclude them from resolving questions of justice which should be at the very heart of political life. As Aristotle taught so long ago, ${ }^{24}$

It is the peculiarity of man, in comparison with the rest of the animal world, that he alone possesses a perception of good and evil, of the just and the unjust, and of similar qualities; and it is association in a common perception of these things which makes a family and a polis.

Giving judges the last word, the definitive say, on issues of social and political justice is to exclude citizens from participation in the essential activity of a political community.

In making this point I do not mean to denigrate the contribution judicial decisions can make to public discussion and consideration of rights issues. Some Charter critics, in my view, have gone too far in denouncing judicial review under the Charter as excessively elitist and undemocratic. These critics tend to underestimate the extent to which legal aid and the organization of advocacy groups have made litigation much more accessible than in the past, as well as the extent to which Charter litigation generates action on law reform issues which are neglected or ignored by legislatures. Also, I would acknowledge that both the presentation of Charter issues before judges and their reasoned decisions on those issues can contribute significantly to public understanding. But I am not persuaded that these benefits are so great as to justify making adjudication always the ultimate

22. E. Barker, Reflections on Government (New York: Oxford University Press, 1958) at 36.

23. Supra, note 4 at 337.

24. The Politics of Aristotle, trans. E. Barker (Oxford: Claredon Press, 1948) at 6. 
means of resolving rights issues. Court decisions on whether restricting where new doctors supported by public medicare can practice is a justifiable restriction of individual freedom, or on whether a French-only sign law is needed to preserve the predominantly French character of Quebec, may well have helped the public understand those issues. But in a democracy that aspires to government by discussion and full participation of its citizens in questions of social and political justice, court decisions should not close off further debate and decision-making in elected and publicly accountable legislatures.

Legislatures, it is true, may act precipitately and make questionable decisions. On occasion their consideration of rights issues may, to use Professor Whyte's phrase, be unduly influenced by "the dominant political winds". ${ }^{25}$ But it is a dreadful distortion to suggest that such impassioned and inconsiderate behaviour is the norm in Canadian legislatures. A reading of legislative debates on justice issues such as capital punishment, criminal procedure, aboriginal rights, and language rights does not find legislators simply pandering for popularity. At the same time we should recognize that, while judges are free from any pressure to curry favour with the public, they are not altogether free from other institutional biases. The Supreme Court's curt opinion in B.C.G.E.U. v. British Columbia upholding the power of a judge to restrict the free speech rights of workers does not shine out as a carefully reasoned and balanced consideration of that issue. ${ }^{26}$ Professor Dale Gibson's article in the last issue of this supplement reveals other instances of judicial bias and self-interest. ${ }^{27}$

In designing the institutional matrix for making decisions on rights issues it is a mistake to look for an error-proof solution. Both courts and legislatures are capable of being unreasonable and, in their different ways, self-interested. By providing a legislative counter-weight to judicial power the Canadian Charter establishes a prudent system of checks and balances which recognizes the fallibility of both courts and legislatures and gives closure to the decisions of neither. A legislature's decision to use the override, it must remembered, is not ultimate. It is good for only five years. After five years it can be reviewed but not without re-opening the issue for public debate and discussion.

If we do anything to section 33 of the Charter, we should reform it, not abolish it. There is need to overcome by constitutional amendment that part of the Supreme Court's decision in Ford which permits standard-form overrides without any obligation on the legislature to identify the specific legislative provision which in its judgment needs protection or the right or freedom which it in its view should not be given priority. Professor Weiler and I have advocated a further amendment which would require that any use of the override be subject to two enactments, one before and one after an

\footnotetext{
25. Supra, note 1 at 356.

26. Supra, note 8.

27. D. Gibson, "The Real Laws of the Constitution" (1990) 28 Alta. L. Rev. 358.
} 
election. ${ }^{28}$ This would ensure a cooling off period and time for second thoughts. What is even more important, it would also ensure broad citizen involvement, thus contributing to the fundamental process value of the override.

\section{TWO TEST CASES}

Discussion of the merits of the override might be more focused by considering two test cases: one in which I think the override should have been used but wasn't, and one in which it was used but a lot of people think it shouldn't have been.

\section{A. THE ELECTIONS ACT CASE}

In 1983, the federal Parliament amended the Elections Act to effectively prohibit private interest groups from funding opposition to candidates or parties during election campaigns. In June 1984, Mr. Justice Medhurst of the Alberta Court of Queen's Bench ruled that this legislation was an unreasonable restriction on the right to freedom of expression. The federal government, with an election pending, decided not to appeal this decision. The federal Elections Commissioner, in order to maintain uniform election rules across the country, applied Justice Medhurst's ruling nation wide, in effect rendering the Elections Act amendment null and void.

It is important to recognize that what is at stake in this case is nothing less than the integrity and fairness of our election process in Canada - no small issue for a democracy! But Justice Medhurst's decision striking down the legislation shows little sensitivity to the complexity or importance of working out an appropriate legislative scheme for democratic elections. His decision fails to address the fairness or effectiveness of imposing spending limits on political parties which do not apply to private interest groups. For Justice Medhurst, such limits can be justified only through "actual demonstration of harm or a real likelihood of harm to a society value..." ${ }^{29}$ He does not carefully examine the evidence presented to him by the federal government showing actual harm. Nor does he provide any indication of the degree or nature of the harm which could justify a limitation. ${ }^{30}$

Professor Whyte has attacked Professor Weiler and me for endorsing the use of the override to reverse Justice Medhurst's decision. ${ }^{31}$ In doing so he states that $\mathrm{we}^{32}$

28. P.H. Russell and P. Weiler, "Don't Scrap Override Clause - It's a Very Canadian Solution" The Toronto Star (4 June 1989) B3. A more extensive discussion of this proposal is contained in Professor Weiler's 1984 article, supra, note 15.

29. National Citizens' Coalition Inc. v. A.G. Canada, [1984] 5 W.W.R. 436 at 453.

30. For an extensive critique of this decision see Janet Hiebert, "Fair Elections and Freedom of Expression Under the Charter" (1990) 24 Journal of Canadian Studies 72.

31. I advocated this use of the override earlier in Peter H. Russell, "The First Three Years in Charterland" (1985) 28 Canadian Public Administration 367, at 377-8.

32. Supra, note 1 at 352 , note 9. 
seem to believe restrictions on political participation is an appropriate policy to adopt in the context of elections and argue that the override should be used to counteract any court decision that protected political participation on the basis of freedom of speech or equal protection of the laws. (Emphasis added.)

Professor Whyte's statement is a grave distortion of our position. Support for one particular restriction on election spending obviously does not entail support for any and all restrictions on participation in elections. I would surmise that Professor Whyte himself favours some legislative regulation of the election process and would not welcome judicial decisions overturning any and all regulations that he favoured.

It is important to understand why Whyte advances such an erroneous and illogical interpretation of our position. He does so, I believe, because he has wrongly dichotomized our institutional choice in making decisions about the proper limits of rights and freedoms: either we accept legislative determinations of these issues as ultimate, or we accept judicial determinations as ultimate. If we accept one legislative determination of such an issue, then we must be prepared to accept any and all legislative determinations, no matter how appallingly illiberal and undemocratic we may find them, as unquestionable and ultimate. It is precisely the override's genius that by providing a basis for a shared responsibility between legislatures and courts in deciding rights issues it enables us to avoid such a drastic either/or choice. It would be most unwise to give the judiciary the ultimate say on how to regulate the electoral process. One inherent weakness of the judiciary's treatment of rights issues under the Charter is a tendency to overlook or give insufficient weight to the ways in which private, non-governmental centres of power can adversely affect the freedom and equality of citizens. Judicially mandated deregulation of the election process could lead to a situation in which large accumulations of private wealth can unduly effect election outcomes. We should not declare closure on legislative discussion and re-consideration of these issues just because a judge has spoken.

\section{B. THE QUEBEC SIGNS CASE}

In December 1988 the Quebec National Assembly used the notwithstanding clause to overcome the Supreme Court of Canada's decision striking down the French-only signs provisions of Quebec's Bill 101. ${ }^{33}$ This use of the notwithstanding clause provoked the sharpest outcry to date against the clause. Much of this outrage came from outside Quebec, but not all of it. The Bourassa government's decision to enact Bill 178, ${ }^{34}$ the legislation invoking the override and requiring French-only outside signs, led to the resignation of four of Bourassa's English-speaking ministers. It prompted Prime Minister Mulroney, whose government enjoyed a strong Quebec base, to declare that the Canadian Constitution was "not worth the paper it was printed on." ${ }^{.35}$ And, of course, I should add

\footnotetext{
33. Supra, note 11.

34. An Act to Amend the Charter of the French Language, S.Q. 1988, c. 54.

3s. The [Toronto] Globe and Mail (8 April 1989).
} 
that the Premier of Manitoba, Gary Filmon, responded to this use of the override by withdrawing the Meech Lake Constitutional Accord from the Manitoba legislature. Many would regard Quebec's enactment of Bill 178 as the decisive turning point in the failure of Meech Lake.

So this use of the override appears to be a "hard" case for supporters of the notwithstanding clause, particularly one, like the present writer, who was an ardent advocate of the Meech Lake Accord. But it is essential to understand that support for a constitutional procedure does not require supporting each and every use of that procedure. Those who believe in judicial interpretation of constitutional guarantees are not necessarily in favour of every judicial interpretation of constitutional rights. No more are supporters of a legislative override logically committed to favouring every use of this power. The key question to ask in the contest of the Quebec Signs case is not whether the Supreme Court or the Quebec National Assembly reached the right decision on the issue at stake, but whether this type of question is one on which the judiciary ought to have the last word.

What Prime Minister Mulroney's rhetoric and the shrill outrage of many others who attacked this use of the override seriously distorted was the nature of the question at issue. To hear them, one would think that what was at stake was nothing less than the essential core of freedom of speech and minority rights. But the central issue in this case was much tougher: to what extent does the need to preserve the predominantly French character of Quebec justify limiting the right to advertise in the language of one's choice?

The Supreme Court, like Quebec's National Assembly, regarded the preservation of the predominance of the French language in Quebec as a "serious and legitimate" 36 legislative objective, one that would justify limiting the right to advertise in the language of one's choice. In Allan Singer Ltd. v. A.G. Quebec, ${ }^{37}$ decided at the same time as Ford, the Court upheld provisions of Bill 101 which for some commercial purposes required the use of French but permitted the use of a second language. In Ford, the Court's only difference with the Quebec legislature was that while the Court was prepared to justify legislation requiring that signs in Quebec be predominantly in French, it had not been demonstrated that signs exclusively in French were necessary to maintain a French "visage linguistique" in Quebec. According to the Court, the specific question of whether a French-only sign law as opposed to a French-predominance sign law was necessary to preserve the predominantly French character of Quebec was "simply not addressed by the materials" before the Court. ${ }^{38}$ In response to this decision, the Quebec legislature after several days of debate and public discussion passed Bill 178, which at least its members regarded as a compromise between the Supreme Court's decision and the overturned provisions of Bill 101: French-only signs outdoors, predominantly French signs indoors.

36.

37.

38.

Supra, note 11 at 778 .

[1988] 2 S.C.R. 790.

Supra, note 11 at 779 . 
It is certainly arguable that Bill 178 is an unsuccessful compromise and that from both a political and administrative point of view it would have been better for those who believe a French-only sign law to be essential for the survival of a predominantly French Quebec to have simply re-enacted the provisions of Bill 101. But that's not the point on which the override's legitimacy should depend. The legitimacy of the override in the context of this case depends on whether or not one believes that Quebec's National Assembly should continue to have any decision-making role on the question of what kind of sign is required after the Supreme Court has spoken on the matter.

In my view this question should be answered in the affirmative. The sign case poses a fundamental issue of political justice concerning the relationship of the rights and interests of two minorities. On the one hand there is the minority of Quebeckers who are not French and their right to express themselves in their own language, and on the other the Francophone Quebeckers who are a vulnerable cultural minority in North America and their right to preserve their distinctive culture. Working out an appropriate balance between these two concerns about minority rights is a profound challenge not only for Quebeckers but for all Canadians. This is not an issue which we Canadians either have withdrawn or should withdraw from consideration by Quebec's legislature for ultimate determination by the Supreme Court. To do so would be to detract too much from the responsibility of Quebeckers and other Canadians for participating in the resolution of a question fundamental to the political justice of the political community they share. I would add that it is extremely doubtful that the unity of Canada could survive an insistence by the rest of Canada that Quebec's legislature be denied a continuing role in deciding what is necessary to preserve Quebec's French character.

\section{THE PERSPECTIVE OF PRINCIPLE}

At the beginning of his article Professor Whyte argues that the future of the override cannot be settled by resort to principle. By this he means that the case for the override cannot be a logical deduction from the "basic constitutional principles" he perceives to be at work in the "formal structure of the Canadian state" - namely, "legalism, democracy and federalism." ${ }^{39}$ The elimination of the override, he argues, is at least as consistent with these principles as its retention. Given that the established principles of our constitution cannot settle the issue, the merits of the override should be assessed on a more prudential basis in terms of "the actual social goods and bads" it is likely to produce and "what will produce the soundest government and fairest society." 40

As I have earlier indicated, I have no difficulty accepting Whyte's suggestion that we not try to judge the override entirely on the basis of our constitutional antecedents. And I agree with him that the override should be judged in terms of what will produce a sound

lbid. 
and fair polity for Canadians. But I do take issue with his treatment of what he regards as Canada's basic constitutional principles and their bearing on the override issue.

I have the least quarrel with Whyte's treatment of the federal principle. He is right in viewing federalism as a check on national majoritarianism and pointing out that judicial decisions enforcing the federal division of powers have significantly constrained Canadian legislatures in the past. But he overlooks an important difference between judicial review based on federalism and judicial review based on a bill of rights. Also, he underestimates the impact of the Charter on the workings of Canadian federalism and on the unity of the country.

When courts strike down legislation on federalism grounds, normally this means that one level of government, but not the other, is precluded from implementing a policy. This is a less drastic result than when legislation is struck down on Charter grounds, for then the judicially vetoed policy, absent the override, is placed beyond both levels of government. It is in this sense that removing the override from the Charter would, contrary to Whyte's assertion, entail a greater shift in the balance of power between legislatures and courts than is inherent in the judicial enforcement of federal limits. Secondly, the Charter does have a centralizing effect on Canadian federalism. The article by Morton et al., also in the most recent issue of this supplement, tracking the judicial nullification of statutes begins to take the measure of the Supreme Court's capacity under the Charter to impose uniform policies on the Provinces. ${ }^{41}$ This centralization of policymaking power, from a normative perspective, may at times have clear benefits for Canadian society. At the same time it may reduce the policy pluralism and diversity that many of us value in federalism. Finally, and from the perspective of national unity, most seriously, as I have already suggested, it is most unlikely that we could retain Quebec as a member of the Canadian federation if we were now to insist on removing the override from the Charter. This is not because the majority of Quebeckers are opposed to rights and freedoms but because they want to keep a reasonable measure of control over their cultural security in their own hands.

But Professor Whyte's elucidation of the principle of legalism gives me much more difficulty than his discussion of federalism. For it is here that he seems to slide into the very mode of analysis he has cautioned us to eschew and to argue, in effect, that regardless of "the goods and bads that are likely to be produced" we must be bound by the implications of his principle of legalism.

Whyte's initial formulation of what he calls legalism - namely "the notion that there are adjudicable public issues"42 - is not problematic. But then he goes on to assert that "we have come to terms with these issues being ultimately adjudicable - not subject to legislative review and revision." Here he seems to be saying that having accepted through

\footnotetext{
41. F.L. Morton, G. Solomon, I. McNish and D.W. Poulton, "Judicial Nullification of Statutes Under the Charter of Rights and Freedoms, 1982-1988" (1990) 28 Alta. L. Rev. 396.

42 Supra, note 1 at 351 .
} 
adoption of the Charter that a great many public issues which were heretofore dealt with by the "political branches" are now to be subject to adjudication, we are ineluctably committed to giving the judiciary ultimate control of these issues. But that surely isn't so. Certainly when the Charter was adopted with an override we Canadians made no such commitment. The question now before us, using Whyte's own criteria, is whether making Charter issues "ultimately adjudicable" will lead to the soundest and fairest system of government.

For reasons already advanced in this article I believe that in terms of both the substance of rights policy and its process it would not be sound even to try to let all the public issues which may be adjudicated under the Charter be ultimately settled by judges. I say "try" because that is the closest we can come to realizing Whyte's ideal of forever removing the Charter from what he calls "a purely political process". The experience of the United States shows what an illusion it is to think that without the possibility of a legislative override, rights issues dealt with by the judiciary are forever withdrawn frow the political process. School desegregation was not withdrawn from the American political process after the Supreme Court in Plessy. v. Ferguson ${ }^{43}$ gave its blessing to "separate but equal", any more than Roosevelt's New Deal legislation was removed from the political agenda after being vetoed by the Supreme Court.

But it is difficult to see why even trying to remove rights issues entirely from the political process should result in "sounder" or "fairer" laws. Professor Whyte asserts that "the capacity of governments to regulate society for the public good has not, yet, been fundamentally hampered by Charter decisions. ${ }^{144}$ Some might consider the damage done in Wilson to government's capacity to provide for an equitable distribution of publicly funded medical services, or in National Citizens' Coalition to government's freedom to follow an election commission's advice on how best to provide fair and effective election laws, as already a refutation of Whyte's dictum. But, let us concede that these decisions have not fundamentally hampered government from "regulating for the public good". The question remains: why is it sound and fair to accept this much judicial damage to effective, socially responsible regulation without the possibility of legislative review and, indeed, risk the possibility that judicial decisions might go further and fundamentally cripple government's effectiveness in providing for the public good? Are the judiciary and the judicial process so inherently superior to the legislature and the processes of ordinary politics that we are justified in running these risks?

Professor Whyte apparently thinks they are. The problem with legislatures, he tells us, is that sometimes they "neglect to calculate the extraordinary impact of legislative measures on particular individuals." ${ }^{\text {"45 }}$ Sometimes too, he says, they simply do not care enough about the injury to some persons' right to tailor measures which will minimize the damage. I agree with Whyte that legislatures certainly do these things, and these are

\footnotetext{
43. (1896), 163 U.S. 537.

44. Supra, note 1 at 353.

45. Ibid. at 355 .
} 
precisely the situations in which we may be well served by Charter-based judicial review. But I would submit that judicial review of legislation under the Charter, in turn, has its own limitations and blind spots. Judges often fail to take into account, and indeed sometimes are exposed to the scantiest of submissions on, the relationship of a challenged law to its total social or policy context. ${ }^{46}$ In Wilson, for example, the British Columbia Court of Appeal, in upholding the "liberty" of new doctors to practice their profession at public expense wherever they wish in the province, did not consider the possible inequity in not extending a similar liberty to other newly graduated professionals in that province or the impact of this decision on the financing of other social programs. ${ }^{47}$ Judges considering Charter challenges to legislation and government regulation may minimize the damage which can be inflicted by private centres of social and economic power on the freedom and equality of the most vulnerable groups in a market economy. It is to his credit that Chief Justice Dickson warned against this possibility. ${ }^{48}$ But we cannot always count on such enlightened judicial leadership or on its being followed.

The art of living with the Charter and with its override is to get the best out of both the judicial and the legislative process in making decisions on rights issues. However, according to Whyte's principle of legalism, we must now put all our eggs in the judicial basket. A legislative back-up, in his view, is too apt to plunge rights issues back into the grubby, unprincipled, partisan realm of "pure politics". It is here that we encounter what I find most unacceptable in Whyte's argument, his disdain for democratic politics.

In his discussion of the democratic principle Whyte rejects, as I would, a simplistic majoritarian conception of democracy. I agree with him that a liberal democracy requires checks and balances and that judicial review based on a constitutional bill of rights is not inherently undemocratic. Where I differ with him on the democratic principle is on how best to enhance and develop our capacity for democratic citizenship. The attempt to remove rights issues, irretrievably, from the arena of popular politics is to give up on what democratic politics at its best should be - the resolution of questions of political justice through a process of public discussion. As I have written before, it "represents a further flight from politics, a deepening disillusionment with the procedures of representative government and government by discussion as a means of resolving fundamental questions of political justice." 49 For me, the legislative override clause is a way of countering this flight from democratic politics. It is a signal that we Canadians have not yet given up on

For a discussion of the institutional weaknesses of the judiciary in deciding policy issues related to constitutional rights, see D.L. Horowitz, The Courts and Social Policy (Washington: Brookings Institution, 1977).

47. For a discussion of this case and of the judiciary's limitations in dealing with labour relations and employment policy issues, see P.C. Weiler, "The Charter at Work: Reflections on the Constitutionalizing of Labour and Employment Law" (1990) 40 U.T.L.J. 117.

48. "...the courts must be cautious to ensure that it [the Charter] does not simply become an instrument of better situated individuals to roll back legislation which has as its object the improvement of the condition of less advantaged person." Edwards Books and Art Limited v. R., [1986] 2 S.C.R. 713 at 779.

49. P.H. Russell, "The Effect of a Charter of Rights on the Policy-Making Role of Canadian Courts" (1982) 33 Canadian Public Administration 1 at 32. 
our capacity for debating and deciding great issues of political justice in a popular political forum.

In the concluding paragraphs of his article Professor Whyte turns to what for many may be the clinching argument against the override - the need for a judicial check against "extreme political reaction." ${ }^{\text {so }}$ It is in moments of "serious political repression," he contends, that we are most in need of cool judicial guardians to check the passions of democracy. Now, I have no doubt that legislative bodies can act unreasonably and fall under the sway of very repressive forces. In the 1950 s we witnessed just that when Mcarthyism held sway in the United States. We also witnessed then how ineffective that country's judicial guardians were in checking that repression. But more fundamentally, I would argue that a democracy which puts its faith as much in its politically active citizenry as in its judges to be the guardians of liberty is stronger than one that would endeavour to vest ultimate responsibility for liberty and fundamental rights exclusively in its judiciary. 